\title{
Journey of a hematopoietic stem cell transplantation center through COVID-19 pandemic: one-year experience
}

\begin{abstract}
Aleksandr A. Siniaev, Marina O. Popova, Yulia A. Rogacheva, Anna A. Spiridonova, Maria Y. Averyanova, Alexander L. Alyanskiy, Bella I. Ayubova, Elena V. Babenko, Evgenii A. Bakin, Ildar M. Barkhatov, Maxim P. Bogomolny, atiana A. Bykova, Alina A. Vitrischak, Maria D. Vladovskaya, Yulia Y. Vlasova, Alisa G. Volkova, Asmik G. Gevorgian, Tatiana L. Gindina, Oleg V. Goloshchapov, Kirill A. Ekushov, Maria A. Estrina, Natalia E. Ivanova, Maxim A. Kucher, Alexei B. Chukhlovin, Kirill V. Lepik, Inna V. Markova, Natalia B. Mikhailova, Elena V. Morozova, Anna A. Osipova, Olesya V. Paina, Dmitrii E. Pevtsov, Anna G. Smirnova, Alexandr N. Shvetsov, Lilia V. Stelmakh, Galina N. Stolbenko, Ludmila S. Zubarovskaya, Sergey N. Bondarenko, Ivan S. Moiseev, Alexander D. Kulagin
\end{abstract}

RM Gorbacheva Research Institute of Pediatric Oncology, Hematology and Transplantology, Pavlov University, St. Petersburg, Russia

Dr. Aleksandr A. Siniaev, RM Gorbacheva Research Institute

E-mail: drsiniaev@yandex.ru

of Pediatric Oncology, Hematology and Transpantation,

Pavlov University, 6-8 L. Tolstoy St., 197022, St. Petersburg,

Russia

Citation: Siniaev AA, Popova MO, Rogacheva YA et al. Journey of a hematopoietic stem cell transplantation center through COVID-19 pandemic: one-year experience. Cell Ther Transplant 2021; 10(3-4): 30-37.

\section{Summary}

Hematopoietic stem cell transplantation (HSCT) is a life-saving procedure for oncological, hematological and non-malignant disorders. Despite global trend for a decrease of transplantation activity in view of the COVID-19 pandemic, we tried to maintain it by taking preventive measures and optimizing infection control in our center.

\section{Patients and methods}

This is an observational study. We collected the performance data of our transplant center from April 2020 to July 2021, i.e., during two waves of the pandemic. The main objectives were to study the influence of COVID-19 pandemic on the workflow of the HSCT center, including morbidity among employees and HSCT recipients, as well as on the transplant activity.

\section{Results}

The first case of COVID-19 infection in St. Petersburg was recorded on March 8, 2020. On March 30, 2020, a national lockdown had been imposed in the Russian Federation. The second wave of COVID-19 started in October 2020. Weekly screening of staff and patients was the main diagnostic tool, in addition to the governmental requirements. In sum, a total of 21702 PCR tests for
SARS-CoV-2 were performed over the study period. As for July 1, 2021, 69.7\% of employees became immune to the virus, due to previous COVID-19 disease, or by vaccination. In 2020, we managed to perform 419 HSCT, including 136 autologous and 283 allogeneic transplants. For comparison, 415 HSCTs were carried out in 2019, with 144 autologous and 271 allogeneic transplants. In 2020, the HSC donorship was shifted towards unrelated donors from the Russian Registry and haploidentical donors. Incidence of COVID-19 among HSCT recipients between April 2020 and July 2021 was $7.3 \%(n=39)$, being $8.6 \%(n=31)$ after allogeneic HSCT, and $4.5 \%$ $(\mathrm{n}=8)$ following auto-HSCT. The median age of patients with COVID-19 was 27 years (4-66). The median term for the COVID-19 onset was 68 days post-transplant (-1 to +2093$)$. In most patients $-29(74.3 \%)$ the HCT CI comorbidity index at the time of transplantation was 0 . The stem cell source were either peripheral blood stem cells $(n=22,56.4 \%)$, or bone marrow $(n=17,43.6 \%)$. Most of the patients achieved complete remission of the underlying disease at the time of HSCT $(n=30,76.9 \%)$. The overall 100-day survival rate among HSCT recipients since the diagnosis of the COVID-19 was $79.5 \%$ (95\% CI $0.609-0.884)$. The mortality rate was $20.5 \%$ $(\mathrm{n}=8)$. The causes of death were as follows: COVID-19$50 \%(n=4)$; secondary infectious complications, $25 \%$ $(n=2)$; relapse of the underlying disease, $12.5 \%(n=1)$; 
hemorrhagic complications, $12.5 \%(n=1)$. The 100 -day cumulative incidence of transplant-related mortality (TRM) among all HSCT recipients was 7\% (95\% CI 0.9 $0.95)$ and $8.7 \%$ (95\% CI $0.88-0.93)$ in 2019 and 2020 , respectively $(\mathrm{p}=0.35)$.

\section{Conclusions}

Due to preventive measures, regular PCR screening, as well as the use of donors from the Russian Registry or haploidentical donors, we managed to maintain HSCT activity at the same level. The COVID-19 morbidity of HSCT recipients was $7.3 \%$, their mortality rate $-20.5 \%$. In summary, the pandemic did not affect transplant-related mortality among the HSCT recipients in our center.

\section{Keywords}

Pandemic, COVID-19, SARS-CoV-2, HSC transplantation.

\section{Introduction}

In 2020, the COVID-19 pandemic has affected virtually all activities, both in Russia and globally [1-5]. The most significant damage occurred to the healthcare system. The first case of COVID-19 in St. Petersburg was registered on March 8, 2020. The nation-wide lockdown had been imposed in Russian Federation since March 30, 2020. Therefore, COVID-19 has become a real challenge for oncology and hematology services in Russia. The main task was to preserve the availability and quality of highly specialized medical care. Hematopoietic stem cell transplantation (HSCT) is a life-saving procedure for hematological patients. Despite the global trend towards a decrease in transplantation activity due to the pandemic, we tried to retain its capacity by introducing preventive measures and optimizing anti-infectious control in our Center. In the present study, we aim to present the workflow at the largest Russian transplant center in the era of COVID-19 pandemic.

\section{Patients and methods}

This work represents an observational study. The main methodology was to collect the data on clinical capacities of our transplant center from April 2020 to July 2021. Since the beginning of the COVID-19 pandemic, a series of measures have been taken at our Center to prevent spreading of the SARS-CoV-2 virus. Appropriate measures at the inpatient units included were as follows: a part of staff members was transferred to remote work; weekly PCR screening of the personnel and patients was arranged; the staff movement in the clinic was minimized, along with mandatory usage of personal protection equipment (PPE). Protection measures for outpatients included mandatory PCR screening of the patients before hospital admission, remote supervision of patients in permissible situations.

The main objectives included studying the influence of COVID-19 pandemic on the workflow of our HSCT Center, and assessing efficiency of the anti-epidemic measures taken. The main tasks were to estimate the rates of transplant-related mortality, incidence of COVID-19 infection in HSCT recipients and the characteristics of this group, to assess possibility of maintaining HSCT performance during the pandemic. The Kaplan-Meier method was used to estimate overall survival (OS) and transplant-related mortality (TRM). The log-rank test used for comparison of cumulative TRM incidence. All the calculations were performed using $\mathrm{R}$ version 3.3.2.

\section{Results}

\section{Medical staff/Healthcare professionals}

The medical staff of the center consists of 494 employees. The median age is 35 years (range 19 to 77 ). The key aspect was to preserve safety and efficiency of healthcare professionals. None of the employees were directly involved in COVID hospitals/red zones. Some of the staff switched to remote work, psychologists for example, who continued to work with the patients online. A total of 27 employees over 65 years old, including 10 medical doctors and 7 nurses, were transferred to self-isolation. In April 2020, due to limited diagnostic facilities, we were able to perform PCR testing for SARS-CoV-2 among employees only when they manifested with fever or respiratory symptoms. But already in May 2020, we started with weekly screening of clinical staff. During the COVID-19 pandemic, we performed a total of 21,702 PCR tests. Due to optimization of laboratory work, the PCR data became available within 24 hours. The symptom-free employees with positive PCR test results or those with mild clinical signs were sent to self-isolation. Employees with signs of respiratory failure were admitted to the specialized hospital for therapy. The movements of personnel within the clinic were minimized as much as possible. Regular use of personal protective equipment was mandatory.

From April 2020 to July 2021, a total of 252 (54.9\%) of healthcare professionals suffered and recovered from COVID-19, including 83 physicians (51.2\%) and 120 nurses (57.7\%) who developed antiviral IgG antibodies in $44.4 \%$ and $48.1 \%$ of the cases, respectively. Other medical and non-medical staff members had documented disease in $55 \%(\mathrm{n}=49)$ with antibody response in $37 \%$ of the cases (Fig. 1). The median time between the first positive and the first negative PCR test was 16.5 days (range 2 to 65). There were no COVID-19-related deaths among healthcare professionals in our Center.

The largest number of COVID-19 cases among our staff was observed during the second wave of COVID-19 (autumn 2020), which correlated with general course of the pandemic in the Russian Federation (Fig. 2).

By July 1, 2021, 119 employees at our Center (25.9\%) have been vaccinated: physicians, $43.2 \%$ ( $n=70)$; nurses, $15.8 \%$ $(n=33)$; other medical and non-medical staff, $18 \%(n=16)$. Thus, $69.7 \%$ of employees $(n=320)$ were immunized against COVID-19, including physicians $(82.1 \%, \mathrm{n}=133)$, nurses $(66.8 \%, \mathrm{n}=139)$, other medical and non-medical staff $(54 \%$, $\mathrm{n}=48$ ) as shown in Fig. 3. 


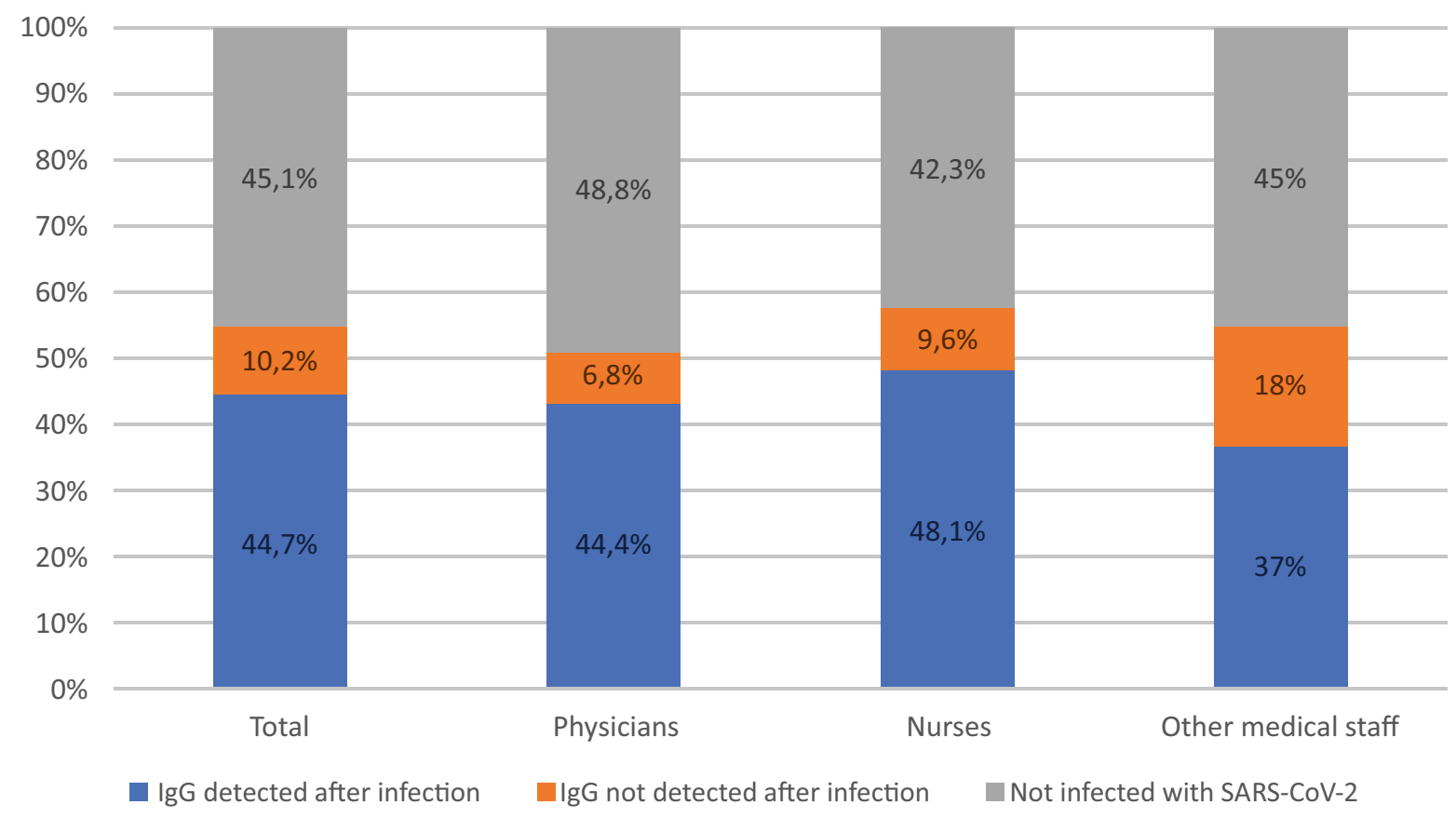

Figure 1. Number of healthcare workers infected with SARS-CoV-2 from the start of pandemic

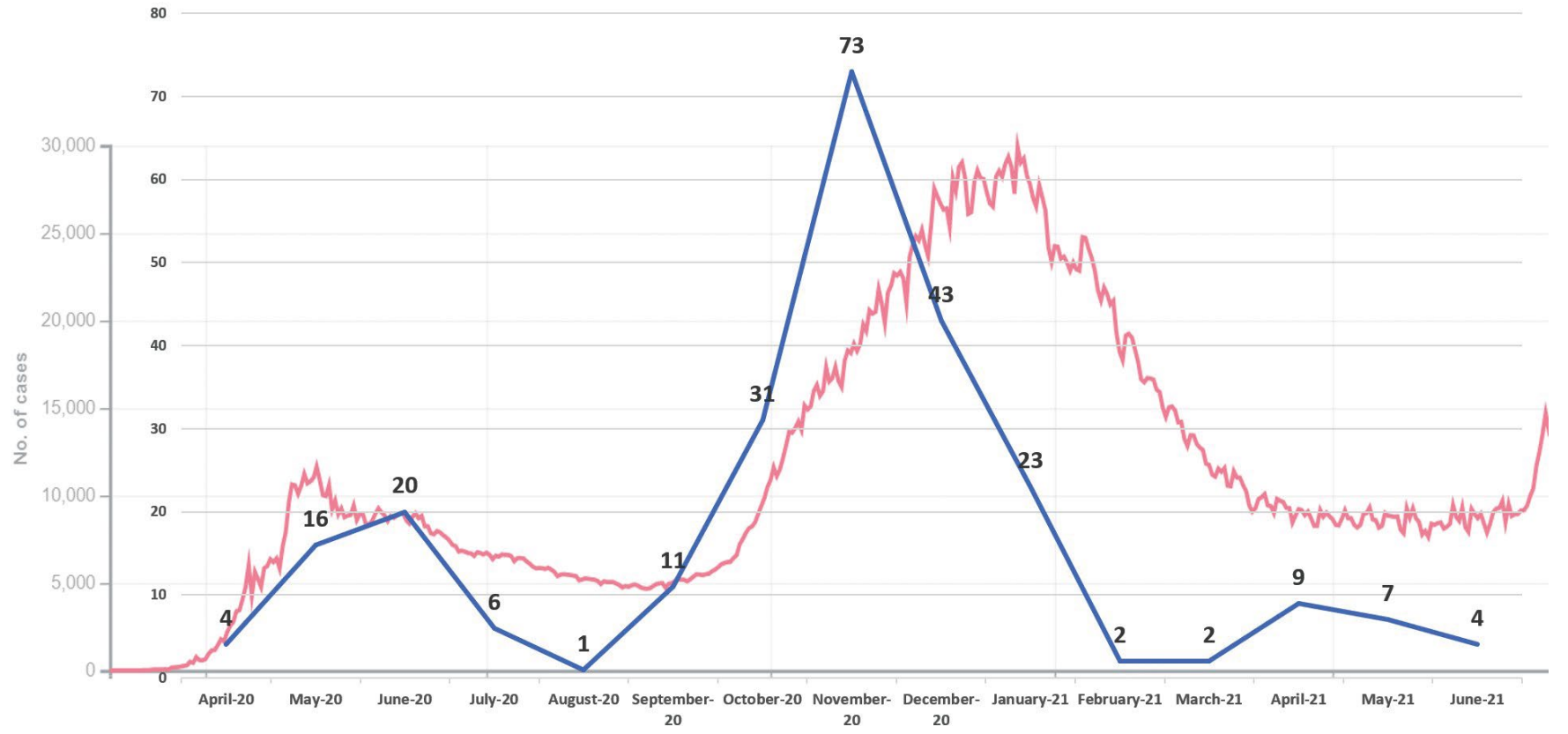

Figure 2. Time dynamics of confirmed cases in RM Gorbacheva Memorial Institute compared to general trends for the Russian Federation

Red curve, dynamics of confirmed cases in Russian Federation; blue curve, time course of confirmed cases in RM Gorbacheva Memorial Institute (St. Petersburg)

\section{Transplant activity in 2020}

A total of 419 HSCTs performed in 2020, included 136 autologous and 283 allogeneic transplants. By comparison, 415 transplantations were performed in 2019, of which 144 and 271 were autologous and allogeneic, respectively (Fig. 4).

Due to closed access to international bone marrow donor registries, the HSCT structure was redistributed in favor of unrelated donors from the Russian registry and haploidentical donors (Fig. 5). During the pandemic from April 2020 to July 2021, 27 allogeneic grafts were cryopreserved and 24 (88.9\%) of them were transfused to HSCT recipients. In 3 cases, graft transfusion was not performed due to recipient death: one patient deceased with COVID-19, two patients, due to progression of the underlying disease. However, we tried to use non-cryopreserved allogeneic grafts whenever 


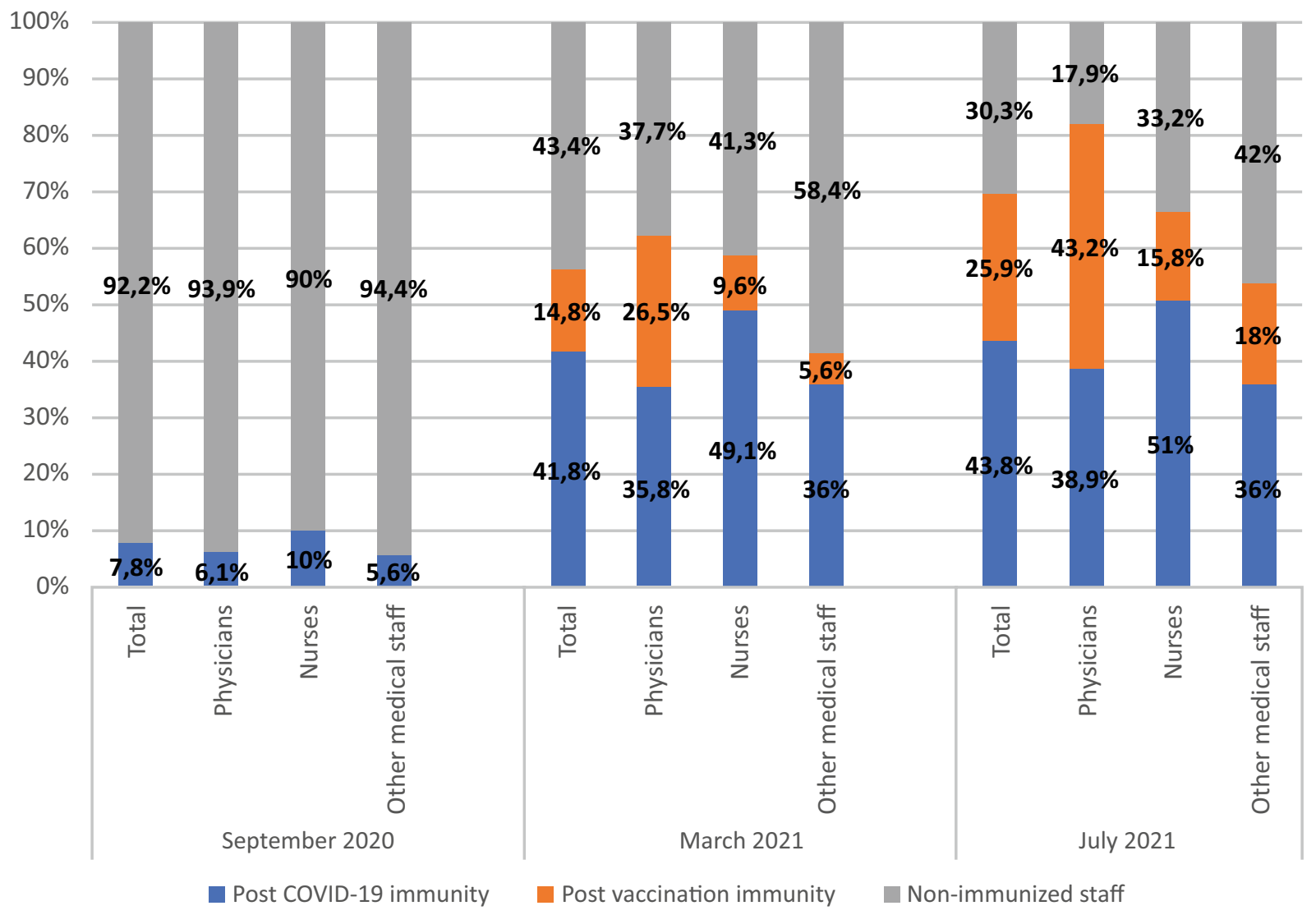

\section{Figure 3. Dynamic of immune response in health-care workers in RM Gorbacheva Memorial Institute through each COVID-19 wave}

possible, and succeeded in $90 \%$ of allografts. The reason for this practice is provided by the data from our center, published in 2018 showing higher frequency of primary graft failure with a cryopreserved allogeneic graft [6]. COVID-19positive cases were recorded in eight donors, of which 6 were scheduled for adult patients and 2, for children. Of these cases, 4 donors were from the Russian unrelated donor registry; 3 donors were haploidentical, and a matched related donor was used in one case. In 4 patients, HSCT was postponed for a 1 to 8 weeks. During this period, no progression of the underlying disease was observed; in these patients, HSCT procedure was performed without complications. In 3 cases, the donor was changed to a haploidentical. In 1 case, a positive PCR test was received after bone marrow harvest, which did not affect the stem cell harvesting or HSCT procedure in any way. Upon receiving a PCR-positive test, donors were sent to self-isolation, and transplantation was postponed due to the absence of alternative donors.

\section{HSCT recipients}

Almost half of the HSCTs performed in 2020 were patients with acute leukemias, i.e., AML, 20.8\% $(n=87)$ and ALL, 26\% $(n=109)$. The detailed diagnosis distribution of HSCT recipients is presented in Table 1.

From April 2020 to July 2021, COVID-19 was diagnosed in 39 HSCT recipients with ALL 11 (28\%), AML 10 (25.5\%), aplastic anemia 5 (13\%), Hodgkin's lymphoma $3(8 \%)$, non-Hodgkin lymphomas 2 (5\%), multiple myeloma $3(8 \%)$, multiple sclerosis $2(5 \%)$ and $1(2.5 \%)$ each with diagnoses

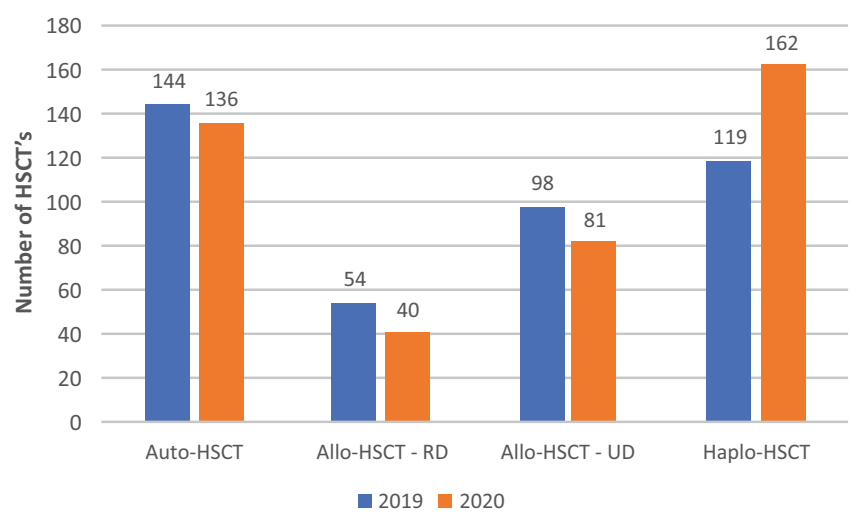

Figure 4. Transplant activity in 2019 and 2020

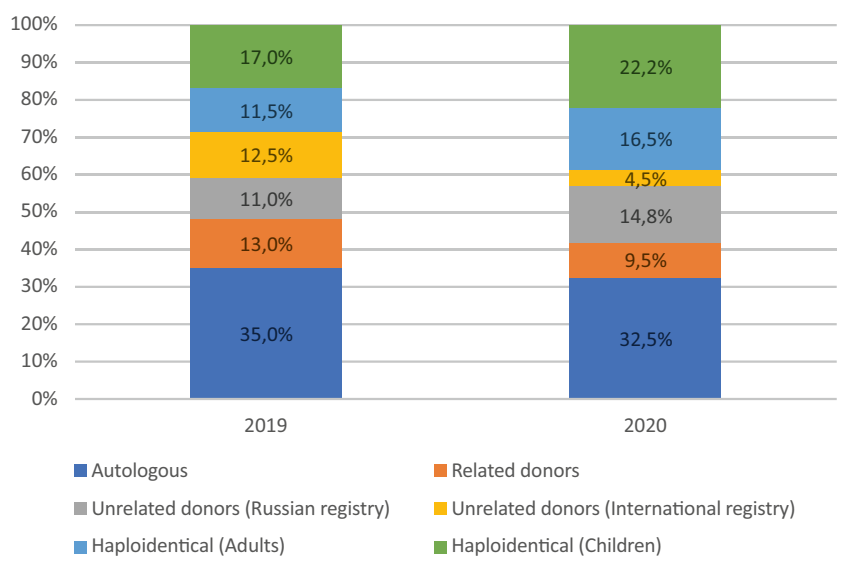

Figure 5. Comparison of HSC donors in 2019 and 2020 
Table 1. Comparison of diagnosis structure in 2019 and 2020

\begin{tabular}{|l|l|l|}
\hline HSCT underlying disease & HSCT number in 2019 & HSCT number in 2020 \\
\hline Aplastic anemia & 22 & 12 \\
\hline Lymphomas & 53 & 44 \\
\hline Myelodysplastic syndrome & 15 & 13 \\
\hline Chronic myeloproliferative disorders & 29 & 33 \\
\hline Acute myeloid leukemia & 72 & 87 \\
\hline Acute lymphoblastic leukemia & 88 & 109 \\
\hline Multiple myeloma & 51 & 49 \\
\hline Inherited metabolic and autoimmune disorders & 16 & 11 \\
\hline Malignant solid tumors & 60 & 46 \\
\hline Multiple sclerosis & 9 & 15 \\
\hline
\end{tabular}

of mucopolysaccharidosis type 1 , chronic myeloid leukemia and CNS embryonal tumors (Fig. 6). During the pandemic, COVID-19 hospital has been deployed at the University, thus enabling continued specific therapies using distant consultation approach for HSCT patients who developed SARS$\mathrm{CoV}-2$ infection. It should be noted that immunosuppressive therapy with calcineurin and mTOR inhibitors as part of the GVHD prophylaxis was continued during the COVID-19 infection.

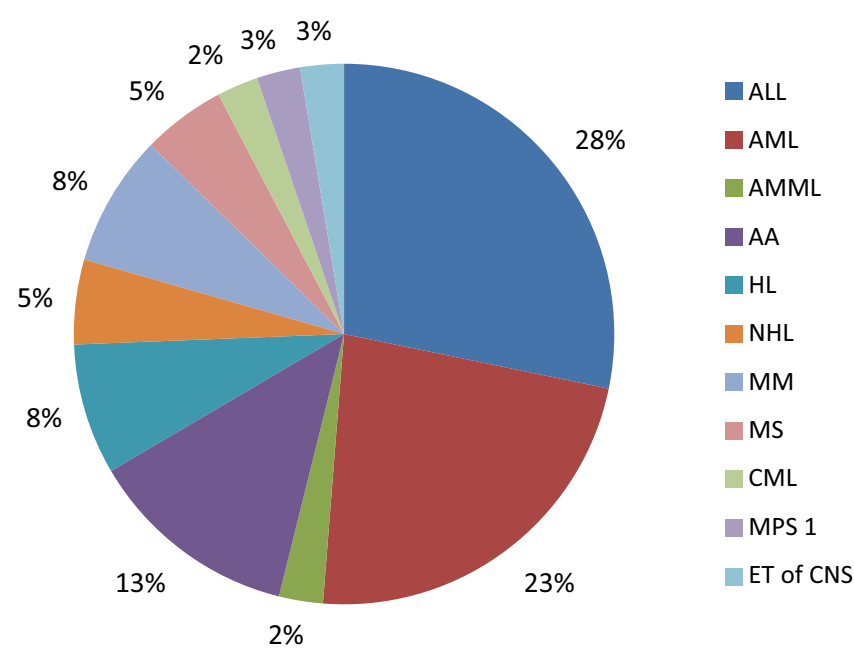

Figure 6. Structure of initial diagnoses in the study group

\section{The overall group characteristics}

The median age of infected patients was 27 years (4-66). There were 25 males $(64.1 \%)$ and 14 females (35.9\%). The majority of patients $(n=29,74.3 \%)$ had 0 points of the HCT CI comorbidity index. Allogeneic and autologous HSCT was performed in $31(79.5 \%)$ and $8(20.5 \%)$ patients, respectively. The HSC source were both PBSC $(n=22,56.4 \%)$, and bone marrow ( $\mathrm{n}=17,43.6 \%)$. Reduced-intensity conditioning (RIC) was used in 27 (69.3\%) patients; MAC, in 12 cases (30.7\%). Thirty patients $(76.9 \%)$ were in complete remission of the underlying disease at the time of HSCT.
The median time between HSCT and COVID-19 infection was 68 days (-1 to +2093). At the time of COVID-19 onset, 33 patients $(84.6 \%)$ were in remission of underlying disease. Most patients had ECOG status of $0-1$ point at the onset of infection [11/18, $(28.2 \% / 46.1 \%)]$. The median cycle threshold value $(\mathrm{Ct})$ for the PCR of the first positive test was 31.8 (14.2-39.2). Two (5.1\%) patients had an active acute graftversus-host disease (GVHD) and $8(20.5 \%)$ patients had chronic GVHD. The median duration of immunosuppressive therapy at the time of COVID-19 development was 36 days $(-1$ to +340$)$.

Coronavirus infection was asymptomatic in 23 (59\%) patients. Febrile fever was recorded in $16(27 \%)$ patients; cough, in $8(14 \%)$; respiratory failure, in 4 (7\%); diarrhea, in $3(5 \%)$; emetic syndrome, in $1(2 \%)$; hypotension in $1(2 \%)$; rhinopharyngitis, in $1(2 \%)$; anorexia, in $1(2 \%)$. The median level of leukocytes was $3.6 \times 10^{9} / \mathrm{L}(0-14.7)$, neutrophils $1.6 \times 10^{9} / \mathrm{L}(0-11.9)$, lymphocytes $-0.9 \times 10^{9} / \mathrm{L}(0-3.2)$, platelets $-115 \times 10^{9} / \mathrm{L}$ (6-298), hemoglobin $-98 \mathrm{~g} / \mathrm{L}$ (58-155).

Seventeen (43.6\%) patients were admitted to the hospital, and $22(56.4 \%)$ were observed as outpatients. The median hospital stay was 15.5 days (1-47). Eight (20.5\%) patients died. The median duration of COVID-19 before death was 20 days (1 to 47). After the infection, 21 (53.8\%) patients were in remission of the underlying disease, $9(23.1 \%)$ were in progression. In $6(15.4 \%)$ patients, the disease staging was not performed due to a lethal outcome, in 2 (5.1\%) patients with diagnoses of MPS type 1 and MS, the staging was not applicable. The disease status at the follow-up point was unknown in 1 patient $(2.6 \%)$. The median period from the diagnosis of coronavirus infection to the follow-up term was 105 days (1-337).

The incidence of COVID-19 among HSCT recipients from April 2020 to July 2021 was $7.3 \%(\mathrm{n}=39)$, in allo-HSCT, $8.6 \%(\mathrm{n}=31)$; in auto-HSCT, $4.5 \%(\mathrm{n}=8)$. A total of 536 HSCTs were performed during this period. The overall 100-day survival rate among HSCT recipients since the diagnosis of the COVID-19 was $79.5 \%$ (95\% CI 0.609-0.884), as shown in Fig. 7A. The mortality rate was $20.5 \%(\mathrm{n}=8)$. Among 8 patients, $50 \%(n=4)$ died in the early post-transplant period up to +100 days, and $37.5 \%(n=3)$ of them had 
pancytopenia at the time of the COVID-19 onset. The causes of death were COVID-19 infection $(n=4,50 \%)$, secondary infectious complications ( $n=2,25 \%)$, relapse of the underlying disease $(n=1,12.5 \%)$, hemorrhagic complications $(n=1$, $12.5 \%)$

The 100-day cumulative incidence of transplant-related mortality (TRM) among all HSCT recipients was 7\% (95\%CI $0.9-0.95)$ and $8.7 \%$ (95\%CI 0.88-0.93) in 2019 and 2020, respectively $(\mathrm{p}=0.35$ ) (Fig. $7 \mathrm{~B})$. The 100 -day cumulative incidence of TRM among auto-HSCT recipients was $1.4 \%$ and $3.8 \%$ (95\%CI 0.9-0.98) in 2019 and 2020, respectively ( $\mathrm{p}=0.33$ ) (Fig. $8 \mathrm{~B}$ ). The 100-day cumulative incidence of TRM among allo-HSCT recipients was $13.9 \%$ and $14.9 \%$ (95\% CI 0.8-0.89) in 2019 and 2020 respectively ( $\mathrm{p}=0.79$ ) as seen from Fig. 8A.

A

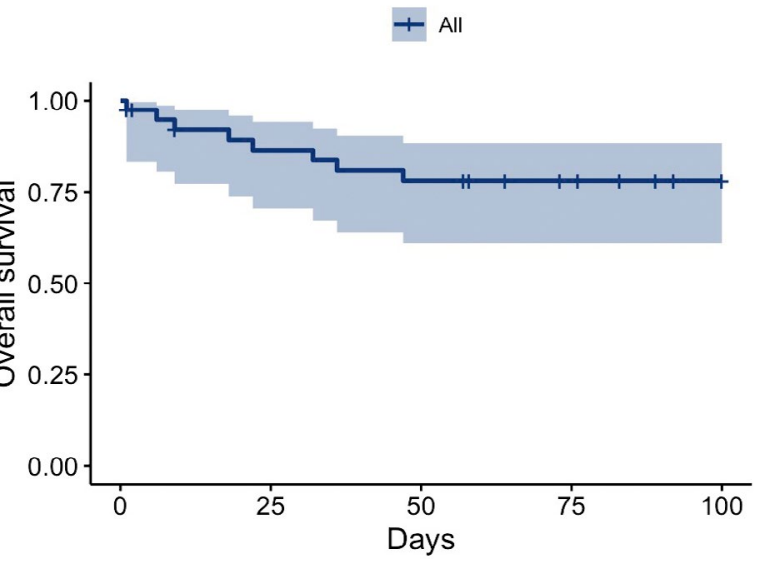

Number of at-risk patients

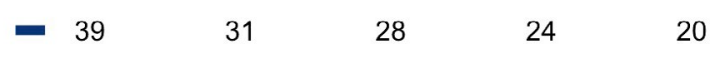

\section{Discussion}

A number of published works to the similar topic point to decreased transplant activity in HSCT centers around the world during the COVID-19 pandemic [7-12]. We tried, however, to keep the same transplant activity. Despite the mortality rate of $20.5 \%$ in the group of HSCT recipients, diagnosed with COVID-19, the one-year TRM did not change significantly compared to 2019. In our opinion, the reason for these results is, firstly, low incidence of COVID-19 infection among HSCT recipients in our Center, and, secondly, maintenance of HSCT activity during the pandemic. This became possible due to the measures taken to limit spreading of SARS-CoV-2, as well as redistribution of the donor structure in favor of unrelated donors from the Russian registry, as well as participation of haploidentical donors.

B
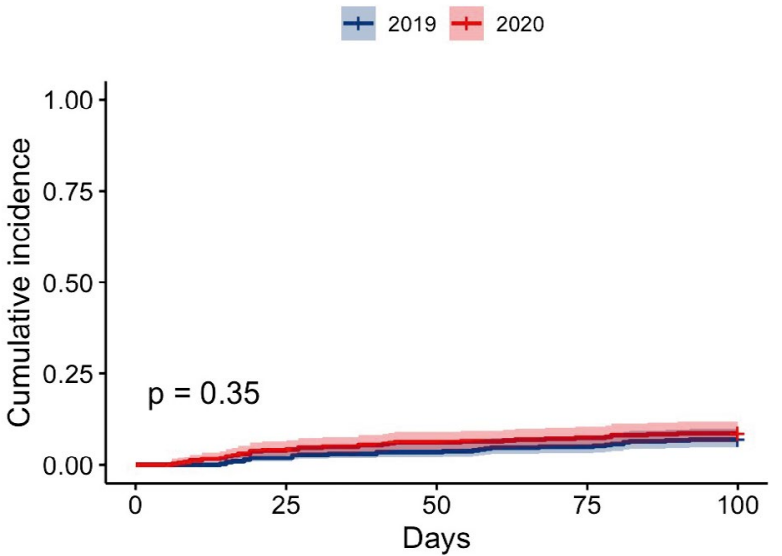

Number of at-risk patients

$\begin{array}{lllll}-414 & 406 & 399 & 393 & 385 \\ -415 & 398 & 389 & 384 & 379\end{array}$

Figure 7. 0verall 100-day survival rate since the COVID-19 diagnosis (A), and 100-day cumulative incidence of transplant-related mortality (B) among all HSCT recipients

A

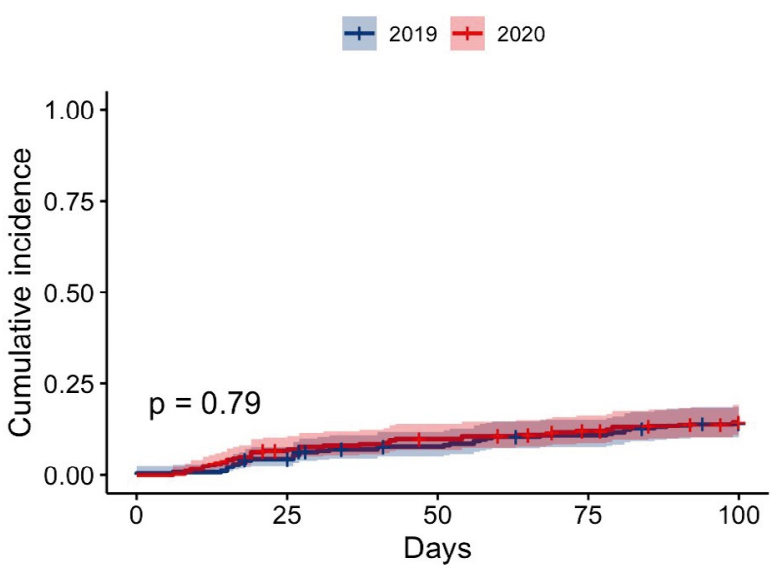

Number of at-risk patients

$\begin{array}{lllll}-271 & 258 & 243 & 234 & 224 \\ -286 & 264 & 254 & 243 & 231\end{array}$

B
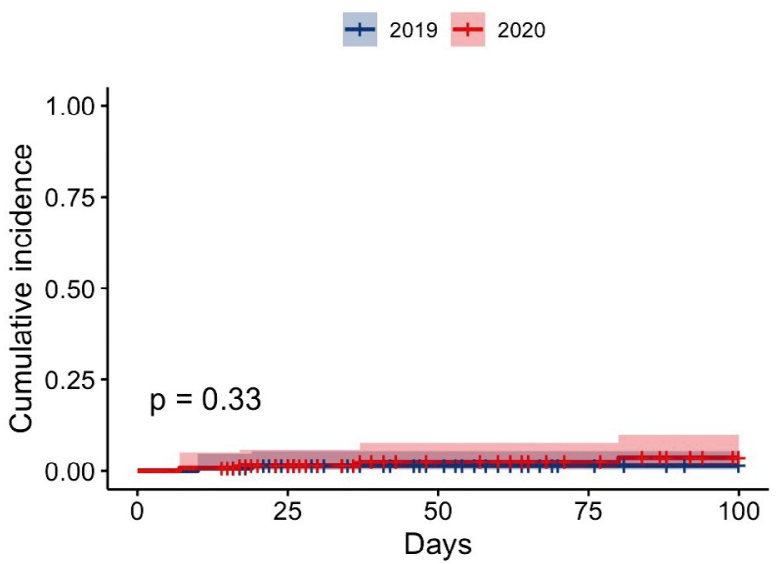

Number of at-risk patients

$\begin{array}{rrrrr}-144 & 132 & 112 & 98 & 93 \\ -136 & 109 & 90 & 81 & 73\end{array}$

Figure 8. Comparison of 100-day transplant related mortality among allo-HSCT (A) and auto-HSCT (B) recipients in 2019 and 2020 


\section{Conclusions}

Our experience confirms that with appropriate patient care resources, thorough screening and selection of donors, regular screening of patients and staff, vaccination, proper use of personal protective equipment, it is possible to maintain the same transplant activity during a pandemic without significantly increased TRM.

\section{Financial support}

This work was financially supported by the Ministry of Science and Higher Education of the Russian Federation (Agreement № 075-15-2021-1086, contract № RF---193021X0015). No conflicts of interest are declared.

\section{Acknowledgement}

Special thanks to the nurses, patients and their relatives.

\section{References}

1. Varma A, Kosuri S, Ustun C, Ibrahim U, Moreira J, Bishop M, et al. COVID-19 infection in hematopoietic cell transplantation: age, time from transplant and steroids matter. Leukemia 34, 2809-2812 (2020). doi: 10.1038/s41375-02001019-x

2. Sultan AM, Mahmoud, HK, Fathy GM, Abdelfattah N. The outcome of hematopoietic stem cell transplantation patients with COVID-19 infection. Bone Marrow Transplant. 2021; 56, 971-973. doi: 10.1038/s41409-020-01094-9

3. Passamonti F, Cattaneo C, Arcaini L, Bruna R, Cavo M, Merli F, et al. Clinical characteristics and risk factors associated with COVID-19 severity in patients with haematological malignancies in Italy: a retrospective, multicentre, cohort study. Lancet Haematol. 2020; published online Aug 13. doi: 10.1016/S2352-3026(20)30251-9

4. Orchard K, Dignan FL, Lee J, Pearce R, Desai M, McFarlane E, et al. The NICE COVID-19 rapid guideline on haematopoietic stem cell transplantation: development, implementation and impact. Br J Haematol. 2021; 192:467-473. https://doi.org/10.1111/bjh.17280

5. Ljungman P, Mikulska M, de la Camara R, Basak G, Chabannon C, Corbacioglu S, et al. The challenge of COVID-19 and hematopoietic cell transplantation; EBMT recommendations for management of hematopoietic cell transplant recipients, their donors, and patients undergoing CAR T-cell therapy. Bone Marrow Transplant. 2020; 55, 2071-2076. https://doi.org/10.1038/s41409-020-0919-0

6. Babenko EV, Moiseev IS, Kanunnikov MM, Alyanskiy AL, Pevcov DE, Frolova AV, et al. Pair-matched study of cryopreserved versus native graft in adult and pediatric recipients of allogeneic hematopoietic stem cell transplantation. Cell Ther Transplant. 2018 7(1), 45-53. doi: 10.18620/ctt$\underline{1866-8836-2018-7-2-45-53}$

7. Xu Z-L, Huang X-J. COVID-19 \& allogeneic transplant: Activity and preventive measures for best outcomes in China. Adv Cell Gene Ther. 2020;00:e94. doi: 10.1002/acg2.94
8. Ueda Oshima M, Sandmaier BM, Petersdorf E, Flowers $M$, Hill G, Lee $S$, et al. Blood and marrow transplantation during the emerging COVID-19 pandemic: the Seattle approach. Bone Marrow Transplant. 2021; 56, 305-313. doi: 10.1038/s41409-020-01068-X

9. Maurer K, Saucier A, Kim HT, Acharya U, Mo CC, Porter J, et al. COVID-19 and hematopoietic stem cell transplantation and immune effector cell therapy: a US cancer center experience. Blood Adv. 2021; 5 (3): 861-871. doi: 10.1182/ bloodadvances. 2020003883

10. Kanellopoulos A, Ahmed MZ, Kishore B, Lovell R, Horgan $\mathrm{C}$, Paneesha S, et al. COVID-19 in bone marrow transplant recipients: reflecting on a single centre experience. $\mathrm{Br}$ J Haematol. 2020; 1, 190: e67-e70. https://doi.org/10.1111/ bjh.16856

11. del Campo PL, López AR, de la Cruz Benito B, de Paz Arias R, de Soto Álvarez T, Sánchez Vadillo I, et al. Hematopoietic cell transplantation during COVID-19 pandemic: experience from a tertiary hospital in Madrid. Exp Rev Hematol. (2021); 14:1, 1-5. doi: 10.1080/17474086.2021.1858789

12. Coll E, Fernández-Ruiz M, Sánchez-Álvarez JE, Martínez-Fernández JR, Crespo M, Gayoso J, et al. COVID-19 in transplant recipients: The Spanish experience. Am J Transplant. 2021, 21: 1825-1837. https://doi.org/10.1111/ajt.16369 


\title{
Через пандемию COVID-19: однолетний опыт центра трансплантации гемопоэтических стволовых клеток
}

\author{
Александр А. Синяев, Марина О. Попова, Юлия А. Рогачева, Анна А. Спиридонова, Мария Ю. Аверьянова, \\ Александр Л. Алянский, Белла И. Аюбова, Елена В. Бабенко, Евгений А. Бакин, Ильдар М. Бархатов, \\ Максим П. Богомольный, Татьяна А. Быкова, Алина А. Витрищак, Мария Д. Владовская, Юлия Ю. Власова, \\ Алиса Г. Волкова, Асмик Г. Геворгян, Татьяна Л. Гиндина, Олег В. Голощапов, Кирилл А. Екушов, \\ Мария А. Эстрина, Наталья Е. Иванова, Максим А. Кучер, Алексей Б. Чухловин, Кирилл В. Лепик, \\ Инна В. Маркова, Наталья Б. Михайлова, Елена В. Морозова, Анна А. Осипова, Олеся В. Паина, \\ Дмитрий Э. Певцов, Анна Г. Смирнова, Александр Н. Швецов, Лилия В. Стельмах, Галина Н. Столбенко, \\ Людмила С. Зубаровская, Сергей Н. Бондаренко, Иван С. Моисеев, Александр Д. Кулагин \\ НИИ детской онкологии, гематологии и трансплантологии им. Р. М. Горбачевой, Первый Санкт-Петербургский \\ государственный медицинский университет им. акад. И. П.Павлова, Санкт-Петербург, Россия
}

\section{Резюме}

Трансплантация гемопоэтических стволовых клеток (ТГСК) - это жизнеспасающая процедура при онкологических, гематологических и доброкачественных заболеваниях. Несмотря на глобальную тенденцию к снижению трансплантационной активности на фоне пандемии COVID-19, мы старались ее сохранить, внедряя профилактические меры и оптимизируя инфекционный контроль в нашем центре.

\section{Материалы и методы}

Это наблюдательное исследование. Мы собрали данные о работе нашего трансплантационного центра с апреля 2020 года по июль 2021 года в течение двух волн пандемии. Основной задачей было изучение влияния пандемии COVID-19 на работу центра ТГСК, включая заболеваемость сотрудников и реципиентов ТГСК, а также трансплантационную активность.

\section{Результаты}

Первый случай заражения COVID-19 в Санкт-Петербурге был зарегистрирован 8 марта 2020 года. 30 марта 2020 года в Российской Федерации был объявлен всеобщий режим самоизоляции. Вторая волна COVID-19 началась в октябре 2020 года. Ocновным инструментом инфекционного контроля, помимо требований государственных органов, был еженедельный скрининг персонала и пациентов. Всего за период с мая 2020 по июль 2021 было проведено 21702 ПЦР исследований. На 1 июля 2021 года $69,7 \%$ сотрудников были иммунизированы в результате перенесенной инфекции или вакцинированы.

В 2020 году, на который пришлась первая волна пандемии, нам удалось провести 419 ТГСК: 136 аутологичных и 283 аллогенных. Для сравнения: в 2019 году выполнено 415 трансплантаций, из них 144 аутологичных и 271 аллогенных соответственно. В 2020 году структура доноров для ТГСК была перераспределена в пользу неродственных из Российского реестра и гаплоидентичных доноров.
Заболеваемость COVID-19 среди реципиентов ТГСК в период с апреля 2020 года по июль 2021 года составила 7,3\% $(\mathrm{n}=39)$, после алло-ТГСК - 8,6\% $(\mathrm{n}=31)$, после ауто-ТГСК - 4,5\% (n=8). Медиана возраста пациентов с COVID-19 составила 27 лет (4-66). Медиана времени развития COVID-19 после ТГСК составила 68 дней (-1-2093). У большинства пациентов - 29 (74,3\%) индекс коморбидности HCT CI на момент трансплантации был равен 0. Источником стволовых клеток были как ПСКК - 22 $(56,4 \%)$, так и КМ - 17 (43,6\%). У большинства пациентов на момент проведения ТГСК была полная ремиссия основного заболевания $(\mathrm{n}=30,76,9 \%)$. Общая 100-дневная выживаемость среди реципиентов ТГСК с момента постановки диагноза COVID-19 составила 79,5\% (95\% ДИ 0,609-0,884). Летальность составила 20,5\% (n=8). Причины смерти: инфекция COVID-19 - 50\% (n=4), вторичные инфекционные осложнения - $25 \%(\mathrm{n}=2)$, рецидив основного заболевания - $12,5 \%(\mathrm{n}=1)$, геморрагические осложнения 12 , $5 \%(\mathrm{n}=1)$. 100-дневная кумулятивная частота трансплантационной летальности среди всех реципиентов ТГСК составила 7\% (95\% ДИ 0,9-0,95) и $8,7 \%(95 \%$ ДИ 0,88-0,93) в 2019 и 2020 годах соответственно $(\mathrm{p}=0,35)$.

\section{Выводы}

Благодаря профилактическим мерам, регулярному скринингу ПЦР, а также использованию доноров, как из Российского регистра, так и гаплоидентичных, нам удалось сохранить трансплантационную активность на прежнем уровне. Заболеваемость COVID-19 среди реципиентов ТГСК составила 7,3\%. Несмотря на то, что летальность от COVID-19 cреди реципиентов ТГСК составила 20,5\%, пандемия не повлияла на трансплантационную летальность среди всех реципиентов ТГСК в нашем центре.

\section{Ключевые слова}

Пандемия, COVID-19, SARS-CoV-2, трансплантация гемопоэтических стволовых клеток. 